\title{
Earthquake in Assam and North Bengal and COVID19 in India
}

\author{
Rusab Baig ${ }^{1}$, Isra Abdul Mateen ${ }^{1}$, Dattatreya Mukherjee ${ }^{2}$ \\ 1. Fourth-Year MBBS Candidate, Shadan Institute of Medical Sciences, \\ Hyderabad, Telangana, India \\ 2. Jinan University. P.R China
}

We are Posting the Outline in OSF Preprint

DOI: $10.31219 / 0$ ff.io/ykp5e

Outline

\section{Earthquake in Assam and north Bengal in India}

On April 28, 2021, a 6.4 Richter scale earthquake affected the Sonitpur district of Assam, the tremors of which were felt in north Bengal and other parts of North-East India, as reported by the National Centre for Seismology ${ }^{1}$. Six more tremors followed the first shake ${ }^{2}$. There were reports of widespread damage to buildings and other structures from across Assam, mostly in the central and western towns of Tezpur, Nagaon, Guwahati, Mangaldoi, Dhekiajuli, and Morigaon ${ }^{3}$. Again on May 3rd, 2021, an earthquake was felt in the Sonitpur district of Assam with a 3.7 magnitude on the Richter scale ${ }^{4}$. Assam disaster management authority reported that 10 people from 4 districts suffered physical injuries since the first attack on April 28, 2021, and some more time will be needed to know about the actual amount of damage that had taken place $^{5}$. According to the National Centre for Seismology, the area affected by the earthquake is seismically very active and falls in the highest seismic hazard zone where the Indian tectonic plate subducts with the Eurasian plate because of which there are high chances of future quakes as well ${ }^{6}$.

\section{COVID-19 current state in Assam}

The first case of COVID-19 in Assam was reported on March 31, 2020. As of 4 May 2021, the State Government has confirmed a total of 89,468 positive cases and 234 deaths in the state ${ }^{7}$. The city of Guwahati has been affected the most. With the second wave of the disease, the cases are rising in the State but the Government claims that they are ready with all the necessary measures ${ }^{8}$.

\section{Impacts of Earthquake on Public Health, Medical attention and Environment amidst COVID-19}

At 7:51 AM in the morning, the first quake woke the people of Assam and they ran out of their homes and other places, without wearing masks in panic, obliterating social distancing and other COVID guidelines amidst the rising number of cases $^{3}$. It was suspected that some people among them were COVID positive and this might 
lead to the future rise in the number of cases in the affected regions of Assam. Many Buildings, Apartments and Malls developed wide cracks. Healthcare facilities such as Dispur Hospital, Apollo Clinic, Down Town Hospital and Excelcare Hospital also saw damages, hampering services amid the surge in COVID-19 cases $^{3}$. At least two persons died in Nagaon and Guwahati due to heart attack, believed to have been caused by the shock and panic triggered by the disaster ${ }^{9}$.

\section{Challenges facing people affected with Earthquake amidst COVID-19 to secure proper healthcare delivery and services}

Roads in Sonitpur and other affected regions have developed wide cracks, which have caused traffic jams ${ }^{10}$. This might have led to a delay in the transport of necessary health services like ambulances and oxygen cylinders from and to the hospitals.

\section{Efforts}

The state disaster management authority launched helplines -- 1070, 1077, 1079 -- to assist people reporting incidents in the aftermath of the tremors, and seek relief. A detailed assessment of the damage is in progress in coordination with District Disaster management authorities, Fire and Emergency services, national and state disaster response forces and experts from Assam Engineering College ${ }^{5}$.

\section{Recommendations}

1. Reallocation of the people from the earthquake-prone area to prevent future casualties and injuries.

2. Deployment of disaster management staff near the earthquake-prone areas such that if any future attack happens then it can be managed by the authorities without any further delay

3. Providing education to the general public not to ignore the COVID appropriate behaviour in times of any such emergencies in the future

4. Assessment of the strength of the buildings and hospitals to withstand earthquakes and relocation of the people from weaker structures to prevent future casualties.

5. Development of earthquake-resistant buildings and structures near the epicentre as that area is prone to have future quakes as well 


\section{References:}

1. Assam, Parts Of North Bengal \& Several North-Eastern States Wake Up To Major Earthquake Tremor. MSN. Accessed May 5, 2021. https://www.msn.com/enin/autos/other/assam-parts-of-north-bengal-and-several-north-eastern-states-wakeup-to-major-earthquake-tremor/vi-BB1g837n

2. Earthquake in Guwahati today: Earthquake of magnitude 6.4 jolts Assam, West Bengal I Guwahati News - Times of India. Accessed May 5, 2021. https://timesofindia.indiatimes.com/city/guwahati/earthquake-of-magnitude-6-4jolts-assam/articleshow/82284326.cms

3. Massive earthquake hits Assam, tremors felt in North Bengal - Telegraph India. Accessed May 5, 2021. https://www.telegraphindia.com/india/massive-earthquakehits-assam-tremors-felt-in-north-bengal/cid/1813933

4. Earthquake Of 3.7 Magnitude Hits Sonitpur Area In Assam: Report. Moneycontrol. Accessed May 5, 2021. https://www.moneycontrol.com/news/trends/current-affairstrends/earthquake-of-3-7-magnitude-hits-sonitpur-area-in-assam-report6850331.html

5. DelhiApril 29 ITWDN, April 29 2021UPDATED:, Ist 2021 02:56. From damage caused to relief operations, Assam earthquake explained in 10 points. India Today. Accessed May 5, 2021. https://www.indiatoday.in/coronavirus-outbreak/story/damage-caused-reliefoperations-assam-earthquake-1796077-2021-04-29

6. Assam earthquake: After 6.4 magnitude jolt, six earthquakes hit Assam's Sonitpur today I India News - Times of India. Accessed May 5, 2021. https://timesofindia.indiatimes.com/india/after-6-4-magnitude-jolt-six-earthquakeshit-assams-sonitpur-today/articleshow/82301590.cms

7. Centre NI. Covid 19 Dashboard - Government of Assam. Accessed May 5, 2021. https://covid19.assam.gov.in/

8. COVID-19 situation in Assam a little alarming, says Health Minister Himanta Biswa Sarma. The New Indian Express. Accessed May 5, 2021. https://www.newindianexpress.com/nation/2021/may/05/covid-19-situation-inassam-a-little-alarming-says-health-ministerhimanta-biswa-sarma-2298474.html

9. Magnitude 6.4 earthquake strikes Assam; 10 injured, buildings damaged. Deccan Herald. Published April 28, 2021. Accessed May 5, 2021.

https://www.deccanherald.com/national/east-and-northeast/magnitude-64earthquake-strikes-assam-10-injured-buildings-damaged-979753.html

10. GuwahatiApril 28 HKN, April 29 2021UPDATED:, Ist 2021 11:34. Assam Earthquake: 6.4 magnitude quake, 7 aftershocks jolt Northeast, tremors felt in Bengal. India Today. Accessed May 5, 2021. https://www.indiatoday.in/india/story/earthquake-innortheast-tremors-felt-in-assam-north-bengal-arunachal-pradesh-1795696-2021-04-28 
